\title{
COLLISIONS INVOLVING ANIMALS: AN OVERVIEW OF THE PROBLEM, RESEARCH METHODS
}

\begin{abstract}
Road collisions with wild animals are influenced by many factors. These include road conditions, time of year and time of day, the location of the road and the vegetation that is located near the road. In addition, an important element is the density of the population hence the number of vehicles on the roads and the factors directly affecting the traffic incident such as the age of the driver and his experience. All of these factors should be carefully examined and monitored in the context of limiting the number of road collisions with wild animals. In many countries, such systems have already been introduced. In Poland at present some research is ongoing, but at the moment its results are not taken into account on a national scale. There is a need for further examination the relationships that directly affect the number of collisions with wild animals, and for this purpose it is necessary to develop accurate methods for the data collection, processing and analysis.
\end{abstract}

\section{INTRODUCTION}

Traffic collisions involving wild animals are the subject of research and analysis in many countries. The scale of the problem is extensive. In Germany, every year 225000 road accidents are caused by collisions with wild animals. In Canada alone in 2008 was over 16000 similar collisions. Countries such as Germany, Sweden, USA, Canada and England recognizing the scale of the problem have set up mechanisms for systematic and accurate collection of data on collisions with wild animals. For this purpose appropriate organizations have been established. In Poland there is no adequate system or organization that would cover this type of event. Authorities such as police, fire and municipal districts or forest districts do not conduct thorough records of the causes of collisions with animals. The authors, after a careful analysis of the data collection methods used by other countries presented the feasibility of collecting data on road collisions with wild animals that can be used in Poland.

\section{COLLISIONS WITH ANIMALS ASPECT OF GLOBAL, NATIONAL AND REGIONAL}

Automobile collisions with wild or domestic animals are currently a widely discussed problem in terms of road safety. In most of the studies are aimed at preventing such incidents road. Countries such as the USA, Canada, Germany and Sweden have already implemented systems to collect and process data on collisions with animals ${ }^{3}$, and in some

\footnotetext{
${ }^{1}$ Krzysztof Tereszkiewicz, DSc, PhD, Eng., Department of Computer Engineering in Management, The Faculty of Management, Rzeszow University of Technology, Rzeszow.

${ }^{2}$ Msc Bartosz Bukała, Department of Computer Engineering in Management, The Faculty of Management, Rzeszow University of Technology, Rzeszow.

${ }^{3}$ S. Borowska, Raport „Śmiertelność zwierząt na drogach w Polsce”, Warszawa 2010.
} 
Scandinavian countries work to create a system for the investigation of road traffic collisions involving animals are well advanced. In spite of the numerous initiatives to improve road infrastructure aimed at reducing the risks of accidents involving animals in many countries, conflicts of this nature is a serious problem. Figures from various sources clearly indicate that the cases of road accidents involving animals are vast. For example, in Germany annually 225,000 collisions take place with animals, in which about 20 people are killed and over 3,000 are injured. In Sweden, yearly recorded are about 4,500 collisions with moose. Agencies responsible for the analysis of these data suggest that these events can be even more than 10,000 per year. This is due not all cases being reported to the police and included in their records 4 .

The country, which actively monitors the scale and effects of car collisions involving animals is Canada. The report presented by the Agency of Transportation and Infrastructure Alberta region shows that in 1991 there were 5,997 collisions with animals, and in 2008 there were 16,322 such events, which gives a very clear increase of approximately $170,00 \%$. It should be noted that collisions with animals do not belong to particular road safety events. The 2008 report indicates that 15950 collisions resulted in property damage, 498 injuries caused to participants in the accident, and nine fatalities ${ }^{5}$.

Also, scientists in the United States recognize the importance of the problem of road traffic collisions with animals. In the literature we find information on the scale of the situation in the United States:

„It is estimated that only in 2003750,000 thousand cases of road traffic collisions with animals mainly involving deer has taken place. As a result, 120 people were killed and 30000 suffered injuries. Total costs associated with losses due to collisions with wild animals is estimated at about $\$ 1.2$ billion a year. ${ }^{6,}$

Detailed studies conducted in State of Minnesota allow to see the true scale of the problem. They show that only in the years 2008 - 2009 have there been 30,479 road accidents involving large mammals. According to data from the North America, the most common cause of road traffic collisions are deer ${ }^{7}$.

In 2003 in England, was appointed the national project called "Deer Vehicle Collision (DVC)," whose purpose is to prevent traffic collisions involving deer. The scale of the problem can provide the data that has been collected by the DVC in the years 2003 to 2010. They report of more than 300000 of this species killed on British roads. From the DVC analysis of 74,000 collisions involving deer outcome that those kinds of accidents caused damage to the total amount of 17 million registered pounds. In these collisions on average about 600 people a year clain for various injuries ${ }^{8}$.

In Poland, the scale of the problem of road traffic collisions involving wild animals is not well recognized. The report of the National Police Headquarters shows that in 2009

\footnotetext{
${ }^{4}$ W. Jędrzejewski, S. Nowak, R. Kurek, R. Mysłajek, K. Stachura, Zwierzęta a drogi. Metody ograniczania negatywnego wpływu dróg na populacje dzikich zwierząt, Wydanie I. Zakład Badania Ssaków Polskiej Akademii Nauk, Białowieża, 2004-84.

${ }^{5}$ A. Carter, Vehicle and Wildlife Collisions, Hunting for Tomorrow, June 2010.

${ }^{6}$ B. Bukała, K. Tereszkiewicz, Kolizje drogowe z udziałem dzikich zwierzatt, oraz doskonalenie metod ich dokumentacji w Stanach Zjednoczonych i Kanadzie, Logistyka 4-2012.

${ }^{7}$ Federal Highway Administration, Wildlife-Vehicle Collision Reduction Study, U.S. Department of Transportation FHWA-HRT-08-034, 2008.

${ }^{8}$ J. Langbein, Collision Course, www.deercollisions.co.uk, 2010.
} 
there was a total of 17,544 thousand events involving animals, in which seven people died and 218 were injured. These statistics seem to be much too low because police sources say that only about $25 \%$ of such cases are reported. In addition, the police collect information only to a limited range, taking into account the fact that an incident involved a wild animal. The reports do not include species data like sex or age and other information that is collected by the police, as in for example, in the United States and Canada 9 .

It should be noted that in the Polish conditions other institutions generally do not collect information about the collisions with wild animals. Those kinds of information cannot be found in GUS sources. For comparison, it should be noted for example in Germany and Norway on the web sites of the respective statistical offices are to be found full monthly and annual statistics on road traffic collisions involving animals. Some data on the problem are provided by forest districts. However, they collect limited information for the purpose of registration of the number of animals to be approved for hunting. National parks are legally obliged to collect data on collisions with animals, but of all 23 parks only 8 in 2009 lead any kind of records. Significantly the largest manager of roads in Poland or the General Directorate for National Roads and Motorways does not collect data and does not have any information about these collisions. Also, any of its affiliates does not collect or analyze data. It is important that at such a scale of construction and upgrading of roads in Poland, taking into account also arranging air corridors and animals overeat further measures are implemented without the source data.

In the Podkarpacie province data related to traffic collisions involving animals are mainly based on information from the Police Headquarters reports. As mentioned earlier the police did not have sufficient data to determine the exact scale of the problem analyzed. The data presented below that may suggest that road collisions with animals are not a problem on a large scale. However it should also pointed out that drivers rarely inform the service road of such cases ${ }^{10}$. Collisions involving animals (data for year 2009), depending on the region are presented in Table $1^{11}$. In Podkarpackie province in 2009 reported a total of 1,006 incidents involving animals of which 9 were accidents. It should be noted that in the structure of the provinces collisions with animals in Podkarpacie province were $5.10 \%$ of the number of events in the country. The most vulnerable in this case are the areas of the Mazovia province, the Wielkopolska province and the Lublin province. It is considered that the main factors determining the severity of road accidents involving animals are on the one hand and population density of traffic flow and the rate of forest cover on the other.

\footnotetext{
${ }^{9}$ Komenda główna policji biuro ruchu drogowego wydział profilaktyki i analiz, Sprawcy wypadków - kierujący pojazdami wg grup wiekowych, Przyczyny i sprawcy wypadków, Wypadki drogowe w Polsce w 2008 roku, Warszawa 2010.

${ }^{10}$ Komenda główna policji biuro ruchu drogowego wydział profilaktyki i analiz, Wypadki drogowe w Polsce w 2011 roku, s. 24, Warszawa 2012.

${ }^{11}$ S. Borowska, Zdarzenia drogowe z udziatem dzikich zwierzat, s. 4, Warszawa 2010.
} 
Table 1. Animal vehicle collisions depending on the region

\begin{tabular}{|l|r|r|r|}
\hline & Number of occurrence & Number of collisions & $\begin{array}{c}\text { Percent of colli- } \\
\text { sions }\end{array}$ \\
\hline TOTAL & $\mathbf{1 7 5 4 4}$ & $\mathbf{1 7 7}$ & $\mathbf{1 0 0 \%}$ \\
\hline the Lower Silesia province & 1215 & 10 & $5,60 \%$ \\
\hline the Kujawy-Pomerania province & 1191 & 8 & $4,50 \%$ \\
\hline the Lublin province & 1481 & 18 & $10,20 \%$ \\
\hline the Lubuskie province & 568 & 1 & $0,60 \%$ \\
\hline the Lódź province & 1365 & 7 & $4,00 \%$ \\
\hline the Małopolska province & 1048 & 10 & $5,60 \%$ \\
\hline the Mazovia province & 1953 & 30 & $16,90 \%$ \\
\hline the Opole province & 574 & 3 & $1,70 \%$ \\
\hline the Podkarpacie province & $\mathbf{1 0 0 6}$ & $\mathbf{9}$ & $\mathbf{5 , 1 0 \%}$ \\
\hline the Podlasie province & 739 & 10 & $5,60 \%$ \\
\hline the Pomerania province & 700 & 14 & $7,90 \%$ \\
\hline the Silesia province & 1338 & 9 & $5,10 \%$ \\
\hline the Świętokrzyskie province & 711 & 17 & $4,00 \%$ \\
\hline the Warmia-Masuria province & 1233 & 10 & $9,60 \%$ \\
\hline the Wielkopolska province & 1561 & 7 & $7,90 \%$ \\
\hline the West Pomerania province & & 7 & $5,60 \%$ \\
\hline
\end{tabular}

Source: S. Borowska, Zdarzenia drogowe z udziałem dzikich zwierząt, str. 4, Warszawa 2010

The data obtained from police statistics for 2011 say that a collision type as a hit on an animal is only $0.40 \%$ of all road traffic collisions (Table 2). In the case of a collision causes $10.90 \%$ are due to collisions with objects located on the road, or animals (Table $3)^{12}$. Data presentation itself makes it clear that collisions with animals are treated synonymously by the police as collisions with objects on the road, which is in conflict with the provisions of the Act on the Protection of Animals, which in Article 1 says: "an Animal, as a living being, capable of suffering, is not an item $[\ldots]^{13,}$.

\footnotetext{
${ }^{12}$ Wypadki drogowe w Polsce w 2011 roku, KGP Biuro Ruchu Drogowego - zespół profilaktyki i analiz, s. 37, Warszawa 2012.

${ }^{13}$ Art. 1, punkt 1,Dz.U. 1997 Nr 111 poz. 724, USTAWA z dnia 21 sierpnia 1997 r.
} 
Table 2 - Collision type (data on year 2011)

\begin{tabular}{|c|c|c|c|c|c|c|c|}
\hline \multirow{2}{*}{\multicolumn{2}{|c|}{ Type of occurrence }} & \multicolumn{2}{|c|}{ Accidents } & \multicolumn{2}{|c|}{ Killed } & \multicolumn{2}{|c|}{ Casualties } \\
\hline & & \multirow{2}{*}{\begin{tabular}{|l|} 
Total \\
11166
\end{tabular}} & \multirow{2}{*}{$\begin{array}{r}\text { Percent } \\
27,90 \%\end{array}$} & \multirow{2}{*}{$\begin{array}{r}\text { Total } \\
696\end{array}$} & \multirow{2}{*}{$\begin{array}{r}\text { Percent } \\
16,60 \%\end{array}$} & \multirow{2}{*}{\begin{tabular}{|l|} 
Total \\
14737
\end{tabular}} & \multirow{2}{*}{$\begin{array}{r}\text { Percent } \\
29,80 \%\end{array}$} \\
\hline Vehicles in & Side & & & & & & \\
\hline traffic & Top & 4240 & $10,60 \%$ & 733 & $17,50 \%$ & 6837 & $13,80 \%$ \\
\hline & Back & 4292 & $10,70 \%$ & 223 & $5,50 \%$ & 5703 & $11,50 \%$ \\
\hline \multirow{7}{*}{ Hit on } & Pedestrian & 10936 & $27,30 \%$ & 1394 & $33,30 \%$ & 10200 & $20,60 \%$ \\
\hline & Tree & 2426 & $6,10 \%$ & 604 & $14,40 \%$ & 3158 & $6,40 \%$ \\
\hline & Pole or sign & 739 & $1,80 \%$ & 84 & $2,00 \%$ & 930 & $1,90 \%$ \\
\hline & Immobilized vehicle & 435 & $1,10 \%$ & 29 & $0,70 \%$ & 537 & $1,10 \%$ \\
\hline & The protective barrier & 373 & $0,90 \%$ & 35 & $0,80 \%$ & 499 & $1,00 \%$ \\
\hline & The animal & 162 & $0,40 \%$ & 3 & $0,10 \%$ & 205 & $0,40 \%$ \\
\hline & The hole, bump & 64 & $0,20 \%$ & 2 & $0,00 \%$ & 77 & $0,20 \%$ \\
\hline \multicolumn{2}{|c|}{ Vehicle roll over } & 2988 & $7,50 \%$ & 243 & $5,80 \%$ & 3804 & $7,70 \%$ \\
\hline \multicolumn{2}{|c|}{ Accident with a passenger } & 685 & $1,70 \%$ & 29 & $0,70 \%$ & 931 & $19,00 \%$ \\
\hline \multicolumn{2}{|c|}{ Other cases } & 1559 & $3,90 \%$ & 108 & $2,60 \%$ & 1880 & $3,80 \%$ \\
\hline \multicolumn{2}{|l|}{ TOTAL } & 40065 & $100,00 \%$ & 4189 & $100,00 \%$ & 49501 & $100,00 \%$ \\
\hline
\end{tabular}

Source: Wypadki drogowe w Polsce w 2011 roku, KGP Biuro Ruchu Drogowego - zespół profilaktyki i analiz, Warszawa 2012

Table 3 - Cause of collision (data on year 2011)

\begin{tabular}{|l|r|r|r|r|r|r|}
\hline \multirow{2}{*}{ Cause of accident } & \multicolumn{2}{|c|}{ Accidents } & \multicolumn{2}{|c|}{ Killed } & \multicolumn{2}{c|}{ Casualties } \\
\cline { 2 - 7 } & Total & \multicolumn{1}{|c|}{ Percent } & Total & Percent & Total & \multicolumn{1}{c|}{ Percent } \\
\hline Items, animals on road & $\mathbf{3 0 4}$ & $\mathbf{1 0 , 9 0 \%}$ & $\mathbf{4}$ & $\mathbf{0 , 8 0 \%}$ & $\mathbf{3 8 5}$ & $\mathbf{1 2 , 3 0 \%}$ \\
sudden driver fainting & 109 & $3,90 \%$ & 9 & $1,80 \%$ & 137 & $4,40 \%$ \\
culpable failure of the vehicle & 88 & $3,20 \%$ & 19 & $3,80 \%$ & 118 & $3,80 \%$ \\
Wrong state of the road & 79 & $2,80 \%$ & 4 & $0,80 \%$ & 100 & $3,20 \%$ \\
Blindness by another vehicle & 27 & $1,00 \%$ & 2 & $0,40 \%$ & 34 & $1,10 \%$ \\
Improperly secured road work & 11 & $0,40 \%$ & - & - & 14 & $0,40 \%$ \\
Improper traffic management & 3 & $0,10 \%$ & - & - & 3 & $0,10 \%$ \\
Vehicle fire & 4 & $0,10 \%$ & - & - & 7 & $0,20 \%$ \\
Transient causes & 956 & $34,30 \%$ & 317 & $63,10 \%$ & 987 & $31,50 \%$ \\
Other causes & 1205 & $43,30 \%$ & 147 & $29,30 \%$ & 1347 & $43,00 \%$ \\
\hline TOTAL & $\mathbf{2 ~ 7 8 9}$ & $\mathbf{1 0 0 , 0 0 \%}$ & $\mathbf{5 0 2}$ & $\mathbf{1 0 0}$ & $\mathbf{3 ~ 1 3 2}$ & $\mathbf{1 0 0 , 0 0 \%}$ \\
\hline
\end{tabular}

Source: Wypadki drogowe w Polsce w 2011 roku, KGP Biuro Ruchu Drogowego - zespół profilaktyki i analiz, Warszawa 2012

It is worth noting that by the year 2009 the Police Headquarters released details of events involving animals, also taking into account the regional statistics. However, in 2011 , it published a generalized statement only limited to summary information for the entire country. 
Important, independent source of information on collisions with wild animals, are the data that were collected through surveys conducted among drivers. Research in this area provide many details of valuable information in this area. It indicates, among others, in which times of year most of these accidents occur. In addition, they are a source of information on what roads the most number of collisions occur. Taking into account these dependencies can be stated that most accidents are reported in the autumn $(39.00 \%)$ and summer $(32.00 \%)$. Hardly any event occurs in the spring $(15.00 \%)$ and winter $(14.00 \%)$. The research also shows that most collisions occur at night $(37.00 \%)$, dusk $(29.00 \%)$ and during the day $(26.00 \%)$. Relatively small as only $8.00 \%$ of these events occur at dawn. Chart 1 presents data on road collisions taking into account the species taking part in them, in the time of the year ${ }^{14}$. By analyzing the different species depending on the season it turns out that the majority of accidents with moose occur in the fall. In the other seasons of the year the amount of collisions with this animal is negligible. Other animals are also victims of accidents mostly in summer and autumn. At minimum collisions with hare are recorded in winter and with boar in spring.

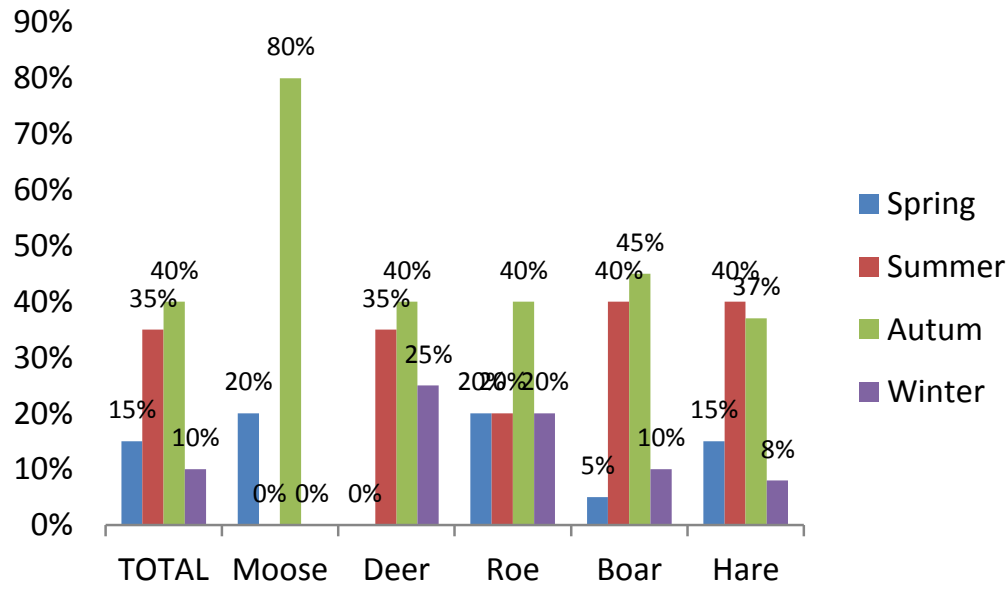

Draw 1 - Road collisions - species and season

Source: S. Borowska, Zdarzenia drogowe z udziałem dzikich zwierząt, str. 4, Warszawa 2010

According to preliminary research conducted by a questionnaire in Podkarpackie province (unpublished data) results show that despite low data indicated by police records collisions with animals is a big problem. Research shows that with $100 \%$ of the drivers involved in the study $89.40 \%$ were involved in a car collision with an animal, of which in $44 \%$ of cases the animal died.

\section{RESEARCH METHODS}

As mentioned in the previous paragraphs, in Poland there are no proven methods of data collection and analysis in a quantitative sense. Most data can be found in the statistics of the police, but they lack detailed information on the animal species, sex, age, and place

\footnotetext{
${ }^{14}$ S. Borowska, Zdarzenia drogowe z udziałem dzikich zwierząt, str. 4, Warszawa 2010.
} 
of the event. Insurance companies and the municipal police do not provide or do not keep records of such events which did not translate into an improved quality of animal safety on the roads.

In the United States, England, Sweden and Germany established the relevant organizations involved in the collection and analysis of data for the prevention of road collisions with wild animals. In Germany, the Department of Accident Research $\left(\mathrm{UDV}^{15}\right)$ Association of German Insurers $\left(\mathrm{GDV}^{16}\right)$ leads collision statistics based on data collected from insurance companies and the police. In Sweden, an organization called the Swedish Transport Agency (Transportstyrelsen ${ }^{17}$ ) receives information from the police (in the case of accidents) and road managers (if you find a dead animal on the road and its surroundings) and prepares an annual report on road accidents across the country. In the United States and Canada, a data collection system seems to be more advanced. To collect data on road collisions with wild animals are not only the police, obliged but also insurance companies, road managers, managers of national parks and forest owners that are crossed by the road.

Data collection is to write down a lot of information, which can be used significantly to further improving road conditions in the context of collisions with wild animals. Data collected include: animal species, sex, age, time of day and year, the exact location of the event (using GPS) information about the state of the animal involved in the collision, and the damage suffered by the driver during the event ${ }^{18}$. At present, the most effective method of research in this area is the surveyed method. Anonymous drivers are more likely to admit to the fact that they participated in a collision with animals.

At present, the most effective method of research in this area is the surveyed method. Anonymously asked drivers are more likely to admit to the fact that they participated in a collision with animals. The study, which was aimed at drivers in Podkarpackie result in that they were able to describe the species that have been involved in an accident, the road number and its immediate surroundings. It follows that the lack of data is not the result of poor memory drivers involved in collisions, but the lack of effective tools for data collection. Currently in Poland it would be crucial to introduce a system that would allow the collection of detailed data in case of a collision with wild animals.

In this case, it is legitimate to take advantage of already developed methods by other countries and implement them on the conditions that are in Poland. The first step is to prepare a form that allows highly accurate registration of the event, taking into account all the features that would give the possibility of a later detailed analysis of the data, and to draw the appropriate conclusions.

This form could be attached to documents drawn up in the road scene, and used by multiple service industry (municipal police, border guards, forest districts, fire service, road service, police, insurance companies, dead animals disposal companies). The authors, based on a survey conducted among drivers Podkarpacie province, and practices in other

\footnotetext{
${ }^{15} \mathrm{http} / / /$ www.udv.de/en/-Insurers Accident Research (Unfallforschung der Versicherer).

${ }^{16} \mathrm{http}: / /$ www.gdv.de/english-2/ - German Insurance Association (GDV).

${ }^{17} \mathrm{http}: / / \mathrm{www}$. transportstyrelsen.se/ - The Swedish Transport Agency.

${ }^{18}$ Federal Highway Administration, Wildlife-Vehicle Collision Reduction Study, U.S. Department of Transportation FHWA-HRT-08-034, 2008.
} 
countries $^{19}$ prepared a proposal for a form that could be used during the collision involving wild animals event registration. A proposed form is listed below.

\begin{tabular}{|c|c|c|c|c|}
\hline \multicolumn{5}{|c|}{ Car-animal collision report (Appendix) } \\
\hline Post number & Case number: & Occurance number: & Filling date & Time: \\
\hline \multicolumn{3}{|l|}{ Localization } & \multicolumn{2}{|l|}{ Distance from the post: } \\
\hline \multicolumn{3}{|l|}{ The exact location (GPS display): } & \multicolumn{2}{|l|}{ The officer intervened: } \\
\hline \multicolumn{5}{|c|}{ Information about the vehicle / weather information } \\
\hline Vehicle model: & & & Date of collision: & Time of collision: \\
\hline \multicolumn{5}{|c|}{ Type of vehicle: car / truck / bus / minivan / Caravan / tractor / other (what kind?) } \\
\hline Estimated damage: & Minimal & Big & Totaled & Other: \\
\hline Time of day & Down & Twilight & Day & Night \\
\hline Road surface type: & Asphalt & Gravel & Dirt & Other: \\
\hline Condition of the road surface: & Dry & Wet & Icy & Snow \\
\hline Weather conditions: & \multicolumn{4}{|c|}{ Sunny / Cloudy / Cloudy / Rainy / Cloudy / Windy / Falling snow / Other } \\
\hline Road description: & Double sharp & Reduction of area & The elevation of the road & Straight road \\
\hline \multicolumn{5}{|c|}{ Have pictures of the vehicle after the collision been taken (YES / NO) } \\
\hline \multicolumn{5}{|c|}{ Information about the animal involved in a collision } \\
\hline Species & & Does the animal died & $\mathrm{S} / \mathrm{NO}$ & \\
\hline \multirow{2}{*}{$\begin{array}{l}\text { The number of animals involved } \\
\text { in the collision: }\end{array}$} & Male & Youngling & Adult & Unknown \\
\hline & Female & Youngling & Adult & Unknown \\
\hline \multicolumn{4}{|c|}{ The dominant vegetation found along the road to the right: } & $\begin{array}{l}\text { Pictures taken } \\
\text { (YES / NO) }\end{array}$ \\
\hline \multicolumn{5}{|c|}{ Please describe the injuries of animal: } \\
\hline How does the animal was remove & ed from the scen & collision: & & \\
\hline
\end{tabular}

Draw 2 - Proposed form of Car-animal collision report.

Source: Own research

The proposed form has been designed for the most detail in describing places of collisions with an animal. It consists of blocks enabling precise description of the road scene and the event date, the date of declaration of the event and the time of the event. Also precise information on the location of the collision based on GPS readings or information from posts on the road.

The next section is responsible for gathering information about weather conditions prevailing at the time of the event, time of year and time of day. In addition, information is collected about road surface conditions, and the type of arrangement. The last section of proposed form is used to collect information about the animal involved in a collision. In this section, data about the animal species, sex or age involved in collisions has to be entered. The form should also include information on the environment of the road in which the event occurred with particular emphasis on the characteristics of the vegetation near. As rightly observed by the authors of the form used by DoTNT (Department of Transportation, Northwest Territories ${ }^{20}$ ) vegetation found on the road is important in the context of emerging animal in their area. The form must include a description of injury to the animal and the way in which dead animals are removed from the scene of the collision. This item appears to be particularly important because in Polish conditions there are widespread cases of dead animals left without their disposal.

\footnotetext{
${ }^{19}$ R. L. Langley, S. A. Higgins, K. Brown-Herrin, Risk Factors Associated With Fatal Animal-Vehicle Collisions in the United States, 1995-2004, Wilderness and Environmental Medicine, 17, 229239 (2006).

${ }^{20}$ http://www.dot.gov.nt.ca/_live/pages/wpPages/home.aspx - Department of Transportation and the Minister of Transportation.
} 


\section{BIBLIOGRAPHY}

[1] A. Carter, Vehicle and Wildlife Collisions, Hunting for Tomorrow, June 2010

[2] B. Bukała, K. Tereszkiewicz, Kolizje drogowe z udziałem dzikich zwierzat, oraz doskonalenie metod ich dokumentacji $w$ Stanach Zjednoczonych i Kanadzie, Logistyka 4-2012

[3] Federal Highway Administration, Wildlife-Vehicle Collision Reduction Study, U.S. Department of Transportation FHWA-HRT-08-034, 2008

[4] J. Langbein, Collision Course, www.deercollisions.co.uk, 2010

[5] Komenda główna policji biuro ruchu drogowego wydział profilaktyki i analiz, Sprawcy wypadków - kierujacy pojazdami wg grup wiekowych, Przyczyny i sprawcy wypadków, Wypadki drogowe w Polsce w 2008 roku, Warszawa 2010

[6] Komenda główna policji biuro ruchu drogowego wydział profilaktyki i analiz, Wypadki drogowe w Polsce w 2011 roku, str. 24, Warszawa 2012

[7] R. L. Langley, S. A. Higgins, K. Brown-Herrin, Risk Factors Associated With Fatal AnimalVehicle Collisions in the United States, 1995-2004, Wilderness and Environmental Medicine, 17, 229239 (2006)

[8] S. Borowska, Raport „Śmiertelność zwierzq̨ na drogach w Polsce”, Warszawa 2010

[9] S. Borowska, Zdarzenia drogowe z udziałem dzikich zwierzat, str. 4, Warszawa 2010

[10] Ustawa z dnia 21 sierpnia 1997 o ochronie zwierząt (Dz.U. 1997 Nr 111 poz. 724)

[11] W. Jędrzejewski, S. Nowak, R. Kurek, R. Mysłajek, K. Stachura, Zwierzęta a drogi. Metody ograniczania negatywnego wpływu dróg na populacje dzikich zwierzat, Wydanie I. Zakład Badania Ssaków Polskiej Akademii Nauk, Białowieża, 2004-84

[12] http://www.udv.de/en/

[13] http://www.gdv.de/english-2/

[14] http://www.transportstyrelsen.se/

[15] http://www.dot.gov.nt.ca/_live/pages/wpPages/home.aspx

\section{KOLIZJE Z UDZIALEM ZWIERZAT: OMÓWIENIE PROBLEMU, METODY BADAWCZE}

Na kolizje z dzikimi zwierzętami ma wpływ wiele czynników. Są to warunki drogowe, pora roku i pory dnia, lokalizacji drogi oraz roślinność, która znajduje się w pobliżu drogi. Ponadto, ważnym elementem jest zagęszczenie populacji, dlatego też istotna jest liczba pojazdów na drogach, jak również czynniki bezpośrednio wpływające na wypadek, np. wiek kierowcy i jego doświadczenie. Wszystkie te czynniki powinny być starannie badane i monitorowane w ramach ograniczenia liczby kolizji z dzikimi zwierzętami. W wielu krajach systemy takie zostały już wprowadzone. W Polsce obecnie kilka badań jest w toku, ale ich wyniki nie są brane pod uwagę w skali kraju. Dlatego tez istnieje potrzeba dalszego badania relacji, które bezpośrednio wpływają na liczbę kolizji z dzikimi zwierzętami, a do tego celu konieczne jest opracowanie dokładnych metod gromadzenia danych, przetwarzania i analizy.

DOI: $10.7862 /$ rz.2012.zim.31 